\title{
DAY LABOURERS IN PRETORIA, WINDHOEK AND THE UNITED STATES - A COMPARISON OF TWO CAPITALS AND A DIFFERENT WORLD ${ }^{1}$
}

\author{
CJ Schenck, University of South Africa \& PF Blaauw, University of Johannesburg, South Africa
}

\begin{abstract}
Purpose: The aim of this paper is to compare the economic dynamics of day labouring in two Southern African capital cities, namely Windhoek and Pretoria, against the background of the experiences of day labourers in a developed country such as the United States.
\end{abstract}

Problem investigated: People waiting at the side of the road, hoping to obtain a piece job for the day, is a typical phenomenon in a situation where people are forced to venture into the informal sector to generate an income. Day labour is a national and international phenomenon that seems to be on the increase. Literature on the similarities and differences across different geographical areas and levels of economic development is limited, however.

Approach: For the purpose of this study, day labourers in Pretoria were the subject of a case study which was compared with studies done in Windhoek and the United States during the same period, namely 2003 to 2004. The general demographics of day labourers in these two cities were investigated, as well as their employment history and the income earned.

Findings and implications: Day labourers in Pretoria and Windhoek were mainly male, fairly young, generally low skilled, earning low and uncertain levels of income and working under harsh conditions. This corresponds to the demographic characteristics of day labourers in the United States. In both the United States and Southern Africa, day labour pays poorly. It was found that day labourers seldom earn more than the subsistence level of income for the respective countries discussed in this paper.

A significant portion of day labourers in Pretoria, Windhoek and the United States previously held formal sector jobs. The biggest difference is to be found in the future prospects of day labourers. The opportunity for day labourers in the United States to make the transition into the formal sector of the economy is far better than for their counterparts in Southern Africa.

Value of the research: The paper expands existing knowledge of day labouring as part of the informal labour market. This is important given the significance of the informal sector in South Africa and Africa at large. It provides a comparison between experiences of the same activity in a developed country and in two cities in developing countries, illustrating important similarities and differences in this regard.

Conclusion: Day labour is a complex phenomenon, and a number of problems, violations and abuses may be found in this sector of the labour market. In order to address these issues successfully, the particular set of circumstances facing day labourers in different areas must be accounted for.

Key words and phrases: day labourers, informal sector, informal employment

\section{INTRODUCTION}

The large numbers of unemployed people remains one of the major macroeconomic problems facing the countries of the Southern African Development Community (SADC). More and more people are therefore forced either to venture into the informal sector of the economy to raise income or to be dependent on other income earners for survival (Whiteford \& Van Seventer, 1999:3). In spite of the fact that the informal sector cannot yet be regarded as a dynamic alternative to formal sector employment, it has seen tremendous growth in Africa and other developing countries during the past decades (Mulinge \& Munyae, 1998:41). The informal sector can act as an employment buffer in the

\footnotetext{
A previous version of this paper was presented at the Southern Regional Science Association 45th Annual Meeting, March 30-April 1, 2006, at the Casa Monica Hotel, St. Augustine, FLORIDA, USA. The authors wish to thank the National Research Foundation, Thuthuka and UNISA for their financial assistance with this research project. The valuable comments of an anonymous reviewer are highly appreciated. The usual disclaimer applies.
} 
urban economy, providing some employment for the large number of people unable to secure employment in the formal sector of the economy (Szirmai, 2005:332).

The large numbers of people waiting at the side of the road, hoping to obtain a piece job for the day, are typical of this trend. Day labour is a national and international phenomenon that seems to be on the increase. In different countries this activity has been given different names. In the United States it is known as day labouring. Namibians refer to it as street unemployed (Gonzo \& Plattner, 2003:41) and in South Africa it is called "those doing piece jobs". In Japan, these day labour pools are known as yoseba (Masami, 2000:1).

On any given day in the United States, approximately 117600 workers are either looking for day labour jobs or are working as day labourers (Valenzuela Jr., Theodore, Meléndez \& Gonzalez, 2006:iii). The estimated figure for South Africa is 45000 people, with Pretoria alone having almost 3000 involved in this activity on a daily basis in 2006 (Harmse, Blaauw \& Schenck, 2008:3). In 2004, the figure for Pretoria was around 2400 day labourers (Blaauw, Louw \& Schenck, 2006:458). They are willing to do anything, from garden work to the mixing of cement, painting, loading or unloading heavy goods.

Gonzo and Plattner (2003) conducted a study among the day labourers in Windhoek, the capital of Namibia. Since the day labourers are not officially registered, their total numbers could not be established with complete accuracy. A random sample could therefore not be used. Instead a nonprobability or convenience sample was used as the best possible alternative. A questionnaire was designed after initial informal interviews were held with day labourers. A total of 300 questionnaires were distributed to the street unemployed. A response rate of well over 50 percent was achieved. The results can therefore be regarded as representative of the population of day labourers in Windhoek (Gonzo \& Plattner, 2003:41).

Valenzuela Jr. et al. (2006) conducted a nation-wide study among day labourers in the United States. The study was based on a country-wide survey of 2660 day labourers. These workers were indiscriminately selected at 264 hiring sites in 139 municipalities in 20 states and the District of Columbia (Valenzuela Jr. et al., 2006:i). This study can therefore be regarded as a very good proxy for the typical situation of most American cities. This allows the data to be used for the purposes of comparing the situation in two Southern African capital cities with the situation in a first world industrialised country like the United States.

Literature on the various informal labour markets in South Africa is often limited. Articles on the subject occasionally appear in the daily press and a few scholarly articles are published. This situation is no different for the informal labour market of day labourers. A study by members of the Department of Social Work at the University of South Africa in the vicinity of the suburb of Elarduspark, in Pretoria, highlighted the fact that these men work long hours and have to wait for employment almost every day in harsh climatic conditions (Schenck \& Louw, 2005:93). This study laid important groundwork in order to extend the research into a more thorough research project, encompassing the whole of Pretoria.

\section{PURPOSE OF THE PAPER}

Against this background, the aim of this paper is to compare the economic dynamics of day labouring in two Southern African capital cities, namely Windhoek and Pretoria, against the background of the experiences of day labourers in a developed country such as the United States. The differences between the developing region of Southern Africa and a developed country like the United States are highlighted where possible. For this purpose, day labourers in Pretoria and Windhoek are used as a case study. The analysis will focus on the basic demographic aspects of the people involved in this informal sector activity. It provides data pertaining to the origin of the people in this part of the informal sector, that is, it tells us whether formal sector employment was once held, for how long and the reasons for losing it. This is done by comparing the income generated from this activity with accepted proxies for the minimum income needed for material survival.

The next section provides particulars of the research methodology employed in conducting the fieldwork for the research. 


\section{METHODOLOGY}

The work that was done by Schenck and Louw (2005:93) laid the basis for the formulation of the questionnaire for the research project in Pretoria. The questionnaire for the survey was designed in the Department of Social Work at the University of South Africa using the methodology followed in similar studies in Los Angeles and elsewhere in the United States. The questionnaire was adapted for South African conditions from the American model used by Valenzuela Jr. et al. (2006:27-33).

The survey took the form of structured interviews. This method ensures that questions could not be misunderstood or misinterpreted (Bless \& Higson-Smith, 1995:111). A questionnaire consisting of four sections was used for this purpose. The first three sections contained questions pertaining to the demographic features and working conditions of day labourers. A section was included to enable information to be extracted regarding the possible abuse of this vulnerable group in the economy.

Twenty third-year and postgraduate students from the Department of Social Work at the University of South Africa were hired as fieldworkers. Two days of training were followed by a trial run of interviews. The final questionnaire was adjusted to take the comments received from the fieldworkers into cognizance. The students also played an important role in formulating and translating the various questions in the appropriate cultural context.

Before the actual survey was conducted a detailed reconnaissance of the greater Pretoria area was done to determine the size of the research population. The estimated number of day labourers in Tshwane was around two thousand four hundred people in 2004.

From this research population a sample population of about 10 percent was included in the survey. The fieldworkers did the fieldwork over a period of four days between the 27th and the 30th of September 2004. During the interviews a total of 242 questionnaires were completed.

The information obtained was analysed and compared with available results for day labouring in Windhoek as well as the data obtained in the United States. With the preceding as background, the next section consists of the presentation and analysis of the empirical results in terms of the stated objectives.

\section{A COMPARISON OF THE DEMOGRAPHIC FEATURES AND WORKING CONDITIONS OF DAY LABOURERS IN PRETORIA, WINDHOEK AND THE UNITED STATES, 2003 TO 2004}

The day labourers in Pretoria in 2004 were almost exclusively male. This can to a large extent be explained by the vulnerable nature of the lives that day labourers lead. Out of the two hundred and forty-two respondents, 88 percent were born in South Africa. The remaining portion was born in Zimbabwe (7 percent) and Mozambique (2,9 percent). Five respondents, 2.1 percent, did not want to specify their country of birth. Presumably these men were also born outside the borders of South Africa. A very interesting observation is the fact that as many as two hundred and fifteen or 88.8 percent of the day labourers interviewed came from outside Gauteng in order to seek employment in Pretoria (Blaauw et al., 2006:462). The fact that Gauteng is the economic heartland of South Africa provides a more than plausible explanation for this observation. In a study by Gonzo and Plattner (2003:48) in Windhoek in Namibia it was found that all but three percent of the day labourers originated from the north of that country.

The situation in a developed country like the Untied States is very different. According to Valenzuela Jr. et al. (2006:iii), the day labour workforce in the United States is predominantly immigrant and Latino. Most of the day labourers there were born in Mexico (59 percent) and Central America (28 per cent). Those born in America only comprise 7 per cent of the total workforce.

Figure 1 illustrates the age distribution of the day labourers in Pretoria in 2004 compared with Windhoek in 2003. 
Figure 1: The age distribution of day labourers in Pretoria in 2004 and Windhoek in 2003

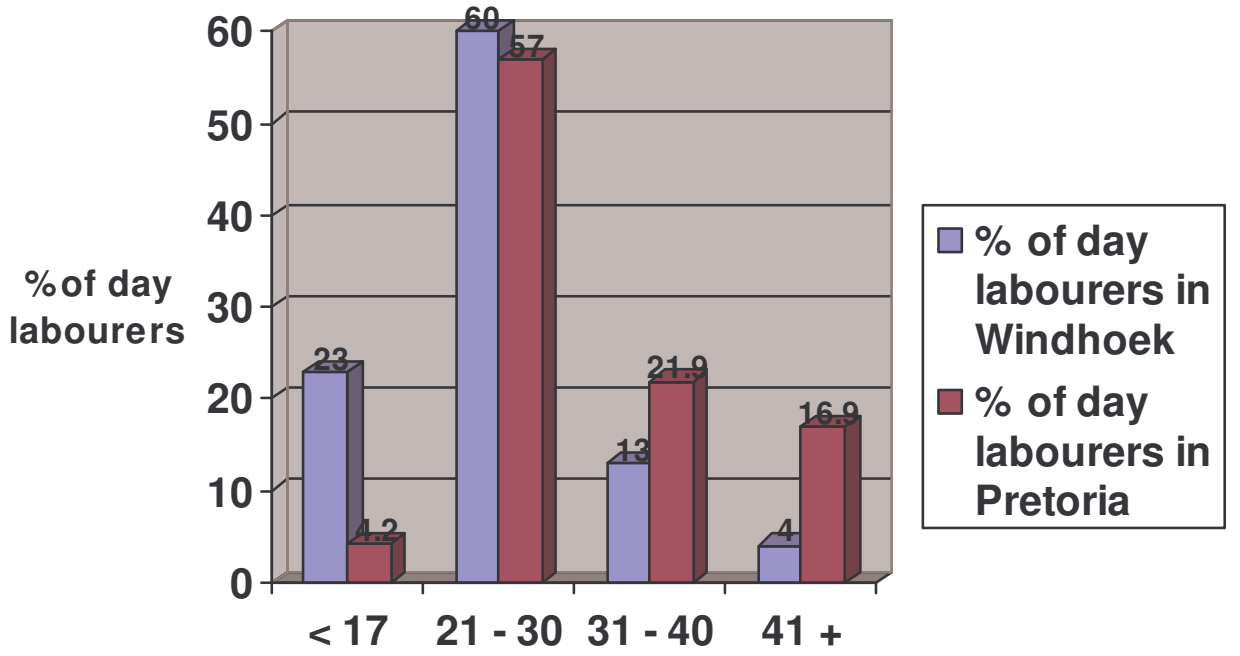

Age of day labourers

Source: Survey data: Gonzo \& Plattner, 2003:47

The overrepresentation of the younger generation is evident in the above figure, even more clearly so in the case of Windhoek. In Windhoek the percentage of day labourers younger than seventeen years of age was more than five times that of Pretoria. In Pretoria, on the other hand, there were over 400 per cent more day labourers in the age group of forty-one years and older. In both capitals the vast majority of day labourers are less than 40 years old. This implies that they fall into the age group that is expected to be the most economically productive one in a nation's workforce (Gonzo \& Plattner, 2003:47). Unfortunately, similar data for the United States were not available, making it impossible to compare this aspect.

Figure 2 compares the marital status of day labourers in Windhoek, Pretoria and the United States.

Figure 2: Day labourers' marital status in Pretoria in 2004, Windhoek in 2003 \& the USA in 2004

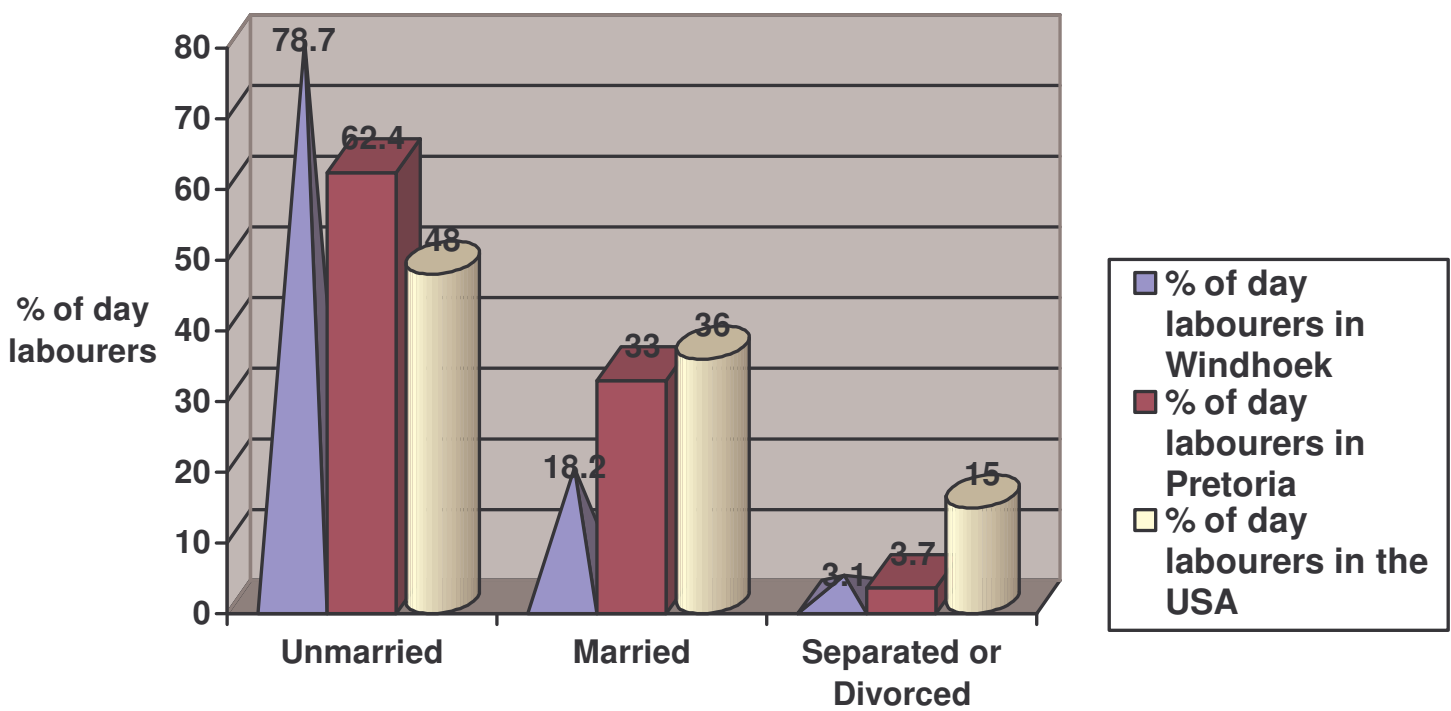

Maritial Status

Source: Survey data; Gonzo \& Plattner, 2003:50 \& Valenzuela Jr. et al., 2006:ii 
The number of day labourers in Pretoria and Windhoek that are married shows a marked difference for the period under investigation. The number of married respondents in Pretoria in 2004 was almost double that of day labourers in Windhoek in 2003. The number of divorced respondents was, however, almost the same for the two cities. It is difficult to comment on the possible reason(s) for this observation. On the one hand it could be an indication that day labourers in Windhoek do not accord the same importance to marriage as their counterparts in Pretoria. It might also be related to the fact that they wait longer before marrying. This is a question that warrants further research.

No important differences were observed in terms of the number of children that day labourers had in both capital cities as well as in a developing country like the United States. Day labourers in Pretoria had on average one or two children in 2004. The majority (33.6 percent) maintain that they have no children and 22,8 and 19,9 percent maintain that they have one and two children respectively. One respondent indicated that he has more than ten children. In Windhoek the number of parents among the day labourers was 59 percent (Gonzo \& Plattner, 2003:51). The corresponding figure for the United States was 63 percent (Valenzuela Jr. et al., 2006:ii). The need for day labourers internationally to earn an income is the result of the number of people to be supported on the income earned.

For example in 2004 in Pretoria, on average, a day labourer supported four people (including himself) on the income earned in this informal labour market. More than half of the respondents (56,2 percent) supported up to four people (Blaauw et al., 2006:462). Of the respondents, 4,1 percent indicated that they support more than nine people on their income. By using the frequency results of the questionnaire it was estimated that the informal labour market of day labourers in Pretoria provided some income for at least ten thousand people (Blaauw et al., 2006:462). This concurs with the theoretical view that informal sector activities like this can act as an employment buffer in the urban economy, providing some income for the large number of people unable to secure employment in the formal sector of the economy (Szirmai, 2005:332).

Day labourers in Pretoria and Windhoek displayed unsatisfactory levels of formal schooling and vocational training. This has a definite impact on the likelihood of obtaining a different position in the formal sector of the labour market. The day labourers in a developed economy, such as the United States, display similar characteristics in terms of formal schooling and vocational training. Figure 3 analyses the years of schooling received by day labourers in Windhoek, Pretoria and the United States.

Figure 3: Years of schooling of day labourers in Pretoria in 2004, Windhoek in 2003 and the USA in 2004

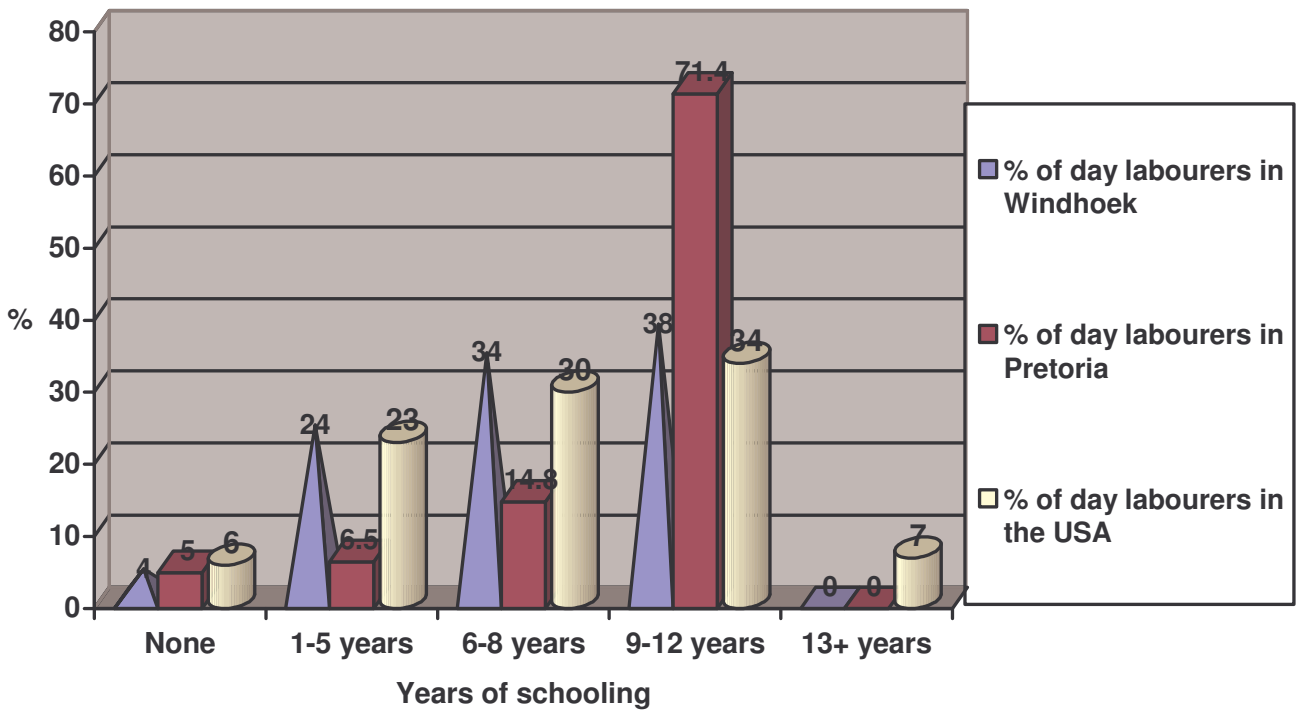

Source: Survey data; Gonzo \& Plattner, 2003:47 \& Valenzuela Jr. et al., 2006:19 
Figure 3 shows a distinctive correlation between the years of schooling of day labourers in Windhoek and the United States, apart from the category of 13 years' schooling or more. This is markedly different from the situation in Pretoria, where the percentage of the respondents that had between 9 to 12 years of schooling outweighed that of Windhoek and the United States by almost a hundred per cent. In the other categories of schooling achievement the day labourers in Pretoria were underrepresented as a natural consequence of the first observation. It is therefore almost a case of all or nothing for day labourers in Pretoria as opposed to a more even spread of opportunities in Windhoek and the United States for that matter.

In both Namibia and South Africa, grade 12 is the highest grade that can be achieved at school level. The relatively high number of day labourers who achieved this qualification points to the fact that their education is wasted in the menial jobs that are available for day labourers in these countries, such as digging in yards, weeding gardens or loading/unloading various goods. In Pretoria, as many as ninetynine (40,9 percent) admitted to having no formal training whatsoever (Blaauw et al., 2006:462). In general, the skills level of the day labourers was found to be very low. The availability and level of skills of the labour force are playing an increasing role in attracting foreign direct investment, which creates future employment opportunities (Chetty, 2002:10). The prospects for a speedy return to the formal sector are therefore not positive at all for the day labourers in Pretoria and Windhoek. In order to effect an improvement in the socioeconomic development of day labourers, emphasis must be placed on the implementation of workforce development strategies that can improve the chances of these people of crossing the divide into formal sector employment. At the same time the improvement of worker protection and increased access to legal services require the same attention as in the United States.

The situation in a developed country like the United States is markedly different. For sixty per cent of these day labourers, this work was the first occupation they had held in the United States. This means that for many workers, day labour is the entry point into the US labour market. Most of them hope to make the transition out of this sector into stable and better paying jobs (Valenzuela Jr. et al., 2006:20).

The survivalist nature of this informal labour market is illustrated by the fact that in Pretoria, Windhoek and the United States, more than half of the day labourers take to the streets in search of employment for five days per week or more. The median average in the case of the United States is six days per week and 34 per cent indicated that they look for employment for all seven days (Valenzuela Jr. et al., 2006:10). In Windhoek the corresponding figure is 56 percent. It can be concluded that the lack of unemployment benefits or social welfare forces unemployed men there to make the extra effort (Gonzo \& Plattner, 2003:61). In Pretoria only 19,8 percent of the day labourers stood on the corner of streets for the whole week. This points to an awareness among day labourers that their chances of obtaining employment on a Sunday in South Africa are not as good as on other days of the week. This difference could possibly also be explained in terms of cultural differences between the day labourers in Windhoek and Pretoria. The culture of the day labourers in Pretoria, for example, dictates that it is customary to set aside Sundays for activities like funerals and church attendance.

The vast majority of the temporary jobs for the day labourers in Pretoria, Windhoek and the United States consist of construction work, gardening services and painting. An interesting number is the 8,3 percent of people that indicated that they were hired to do domestic work in Pretoria in 2004. This corresponds to the percentage of the sample population that consisted of females (Blaauw et al., 2006:463). In comparison, 64 percent of day labourers in the United States did domestic work at some stage (Valenzuela Jr. et al., 2006:10). This can further be explained by the cultural phenomenon in South Africa that domestic work is the domain of women, and that very few women are day labourers.

In summary, day labourers in both Pretoria and Windhoek were found to be mainly male, fairly young and generally very low skilled. They were also supporting a number of people on their income and working under harsh conditions. These characteristics are also applicable in a developed country like the United States, according to the available research results.

The next section analyses the dynamics of day labourers in Pretoria compared with their counterparts in Windhoek and the United States in terms of employment history, income earned and future prospects. 


\section{THE EMPLOYMENT DYNAMICS OF DAY LABOURERS IN PRETORIA, WINDHOEK AND THE UNITED STATES, 2003 TO 2004}

Determining how many of the current day labourers had full-time employment before becoming day labourers can provide valuable insight into the stocks and flows of this informal labour market. Some 102 of the respondents in the 2004 Pretoria survey indicated that they had held permanent employment in the formal sector of the economy before becoming day labourers. This represents a significant 42.1 percent of the sample. The study by Gonzo and Plattner (2003:52-53) indicated that some 61 percent of the day labourers in Windhoek had some previous employment. A large number of them have lost that employment more than three years ago and have subsequently found it difficult to find alternative full-time employment. They can be therefore considered as being long-term unemployed.

The situation in a developed country like the United States is similar, but some important differences are concealed beneath the statistics. More than half or 57 percent of the day labourers in the United States have held a permanent job previously. This was mainly in the construction industry, restaurants and the manufacturing industry (Valenzuela Jr. et al., 2006:20). For many of these people, day labour may offer a source of income, while they search for another permanent job elsewhere in the local economy.

The biggest difference is in terms of the time that day labourers in the United States are involved in this informal sector activity. In 2004, 74 percent of American day labourers were involved in this activity for less than three years (Valenzuela Jr. et al., 2006:ii). This suggests that the opportunity for them to make the transition into the formal sector of the economy is far better than for their counterparts in Southern Africa. It is much more difficult for the day labourers to obtain alternative employment opportunities in the formal sector of the economy in Pretoria and Windhoek. This is partly because the supply outweighs the demand for low-skilled labour and the demand for low-skilled labour in South Africa is continuously declining as well (Loots, 1998:332).

In Pretoria and Windhoek, most of the respondents previously worked in the construction and maintenance sector as well as in the services sector of the formal economy.

In order to further appreciate the dynamics of this activity, it is important to establish the reasons for the termination of the formal sector employment that was once held by these day labourers. Figure 4 shows the reasons provided by these day labourers for leaving their previous employment. The reasons are categorised in accordance with the stock-flow model of the labour market (McConnell, Brue \& Macpherson, 2008:541). The number of workers in each category is again expressed as a percentage of the relevant subsamples, in this case those who were previously employed.

Figure 4: Reasons for terminating previous formal sector employment by day labourers in Pretoria (2004) and Windhoek (2003)
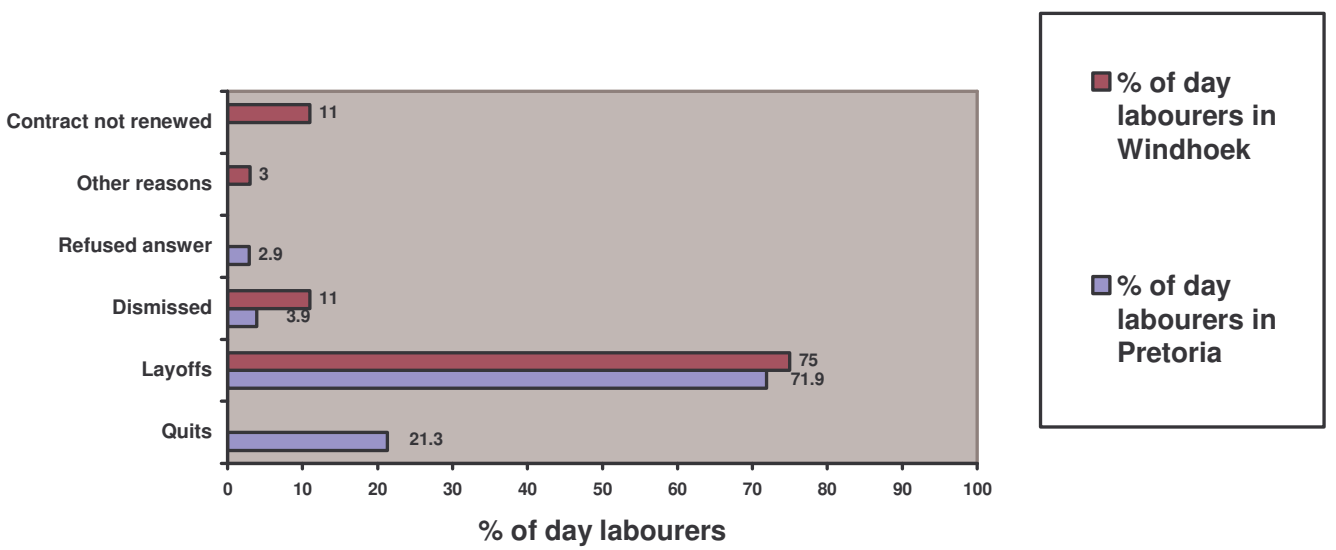

Source: Survey data; Gonzo \& Plattner, 2003:55 
The data shows that two main reasons were reported by day labourers in both cities for the flow from formal sector employment to the condition of being unemployed. Layoffs in the form of retrenchments and the closure of businesses in Pretoria and Windhoek were responsible for 71,9 and 75 percent of the flow respectively (Gonzo \& Plattner, 2003:52-53). The assumption is that this is for the most part related to the business cycle and other economic reasons. Although economic aspects play a major part in this process, there are important institutional factors at play as well. The six female day labourers encountered in the Pretoria study are a case in point. They were all part of a bigger group of about twenty female workers in a dressmaking business. According to reports received from the fieldworkers they maintain that they were laid off in order for the business to stay smaller than the minimum size prescribed by the current labour legislation in South Africa in terms of minimum wages and other conditions of employment. The business now hires the same workers as casual staff, in this way avoiding all the institutional costs involved in adhering to all the prescriptions of the relevant labour legislation (Blaauw et al., 2006:466). Retirements and voluntarily withdrawals played no role in explaining this movement.

A surprising statistic that emerged in Pretoria is the fact that more than twenty per cent of the respondents quit their full-time employment for reasons such as a wage that was considered to be too low, bad relationships with their employers and health reasons. A further 3,9 percent lost their jobs as a result of disciplinary issues (Blaauw et al., 2006:466).In order to complete the comparison between the two cities, it is necessary to analyse the income earned by the people involved in this informal labour market.

\section{AN ANALYSIS OF THE INCOME GENERATED BY DAY LABOURERS IN PRETORIA, WINDHOEK AND THE UNITED STATES, 2003 TO 2004}

Only 30,1 percent of the day labourers in Pretoria were re-hired more than three times by the same employer in 2004. This paints a different picture from known findings in the United States. More than two-thirds or 69 percent of day labourers there are hired repeatedly by the same employer, suggesting a pattern of satisfied employers and willing workers (Valenzuela Jr. et al., 2006:9). The 2004 survey in Pretoria revealed that those day labourers who were hired repeatedly by the same person earned R796,32 on average during the month preceding the interview, while those not re-hired repeatedly by the same person earned significantly less, namely R614,68. The situation in Windhoek in 2003 was by no means better.

The study by Gonzo and Plattner (2003:64) in Windhoek has shown that the day labourers there are paid on the basis of completion of a job. This is independent of their labour input or the amount of time it takes to complete a task. Figure 5 shows the low levels of payment received by day labourers per job in Windhoek in 2003.

Figure 5: Payment received for a job among day labourers in Windhoek (2003)

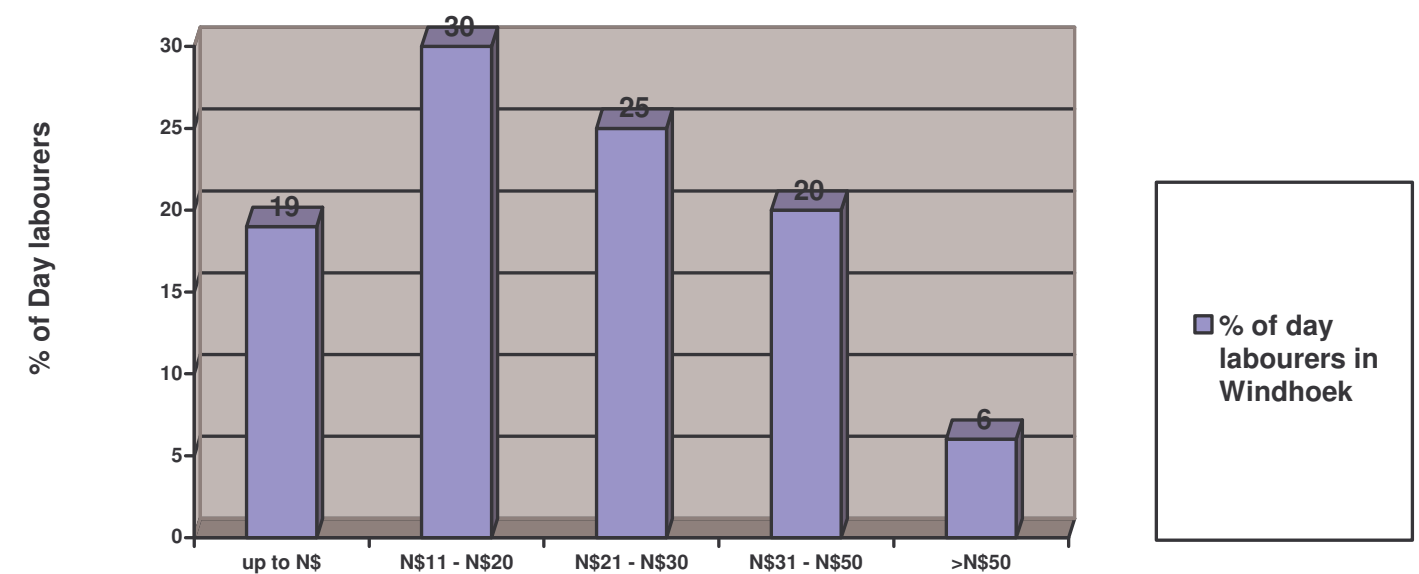

Earnings in N\$

Source: Gonzo \& Plattner, 2003:64 
Gonzo and Plattner (2003:64) postulate the following:

The financial situation of Namibian "street unemployed" can best be described as desperate... Three quarters of the investigated "street unemployed" earn less than $N \$ 30^{2}$ per job, a shocking result, especially in light of the fact that the majority of the respondents either get only one job per week or nothing at all. In addition, $83 \%$ of the respondents declared that they have no other means of income. These income figures are better understood when one considers that Windhoek is one of Africa's most expensive cities and $N \$ 30$ per week is by far not enough for food, let alone accommodation and other basic needs.

The low levels of income received by day labourers in Pretoria and Windhoek are not their only problem. The uncertainty in terms of the income that can be earned in this informal labour market is a major concern. Even in a developed country such as the United States the hourly wages and monthly/annual incomes of day labourers tend to be extremely volatile (Valenzuela Jr. et al., 2006:9). Figure 6 illustrates this volatility graphically.

Figure 6: monthly earnings of day labourers in the United States in June/July 2004, a good month and a bad month (2004)

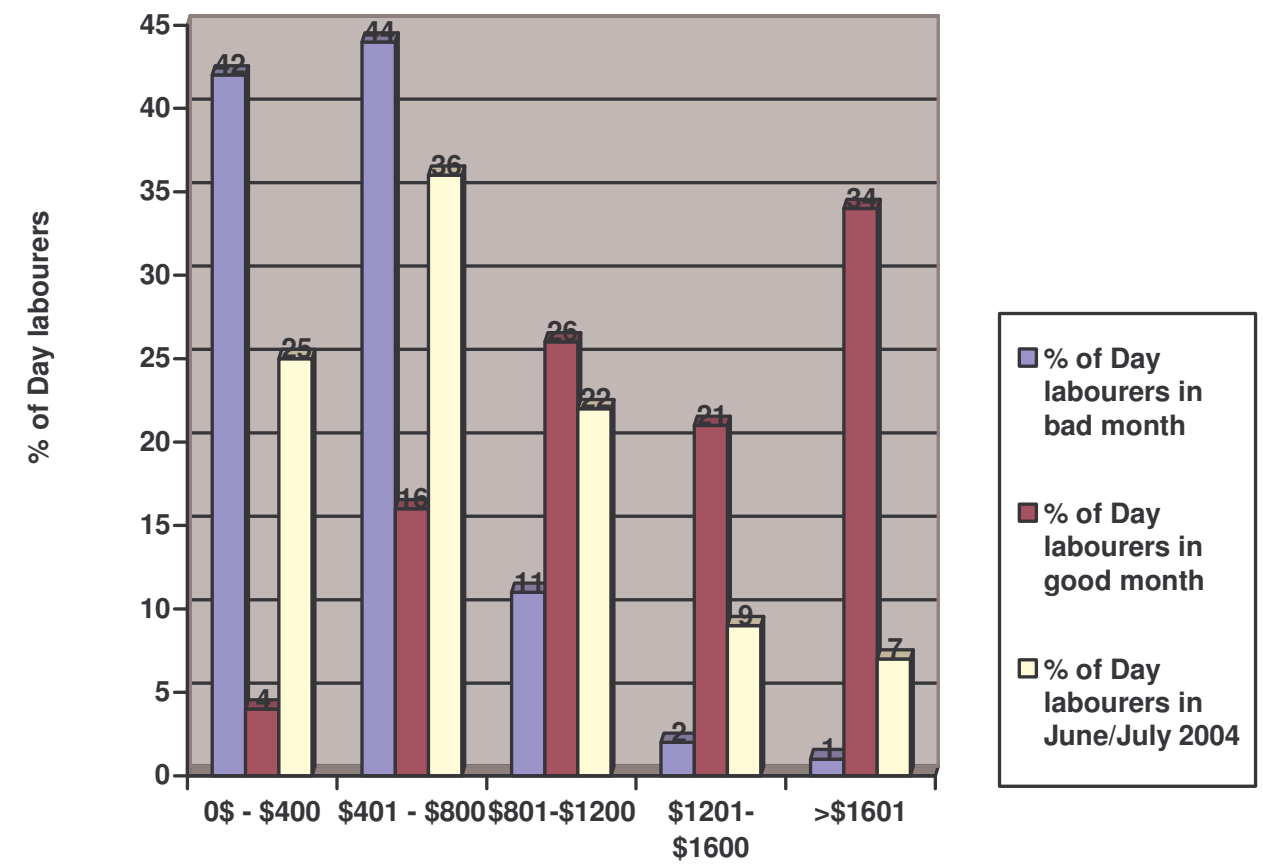

Earnings in US\$

Source: Valenzuela Jr. et al., 2006:11

Valenzuela Jr. et al. (2006:11-12) state the following: "The volatility of monthly earnings can best be observed by comparing the earnings distribution of day laborers' peak (i.e., good months) and slow (i.e. bad months) periods. The median earnings level in a good month rises to $\$ 1400$. However, in a bad month, median earnings fall to just 36 percent of peak period levels, or $\$ 500$. Therefore, even in cases where day labourers have many more good months than bad months, it will be unlikely that their annual earnings will exceed \$15,000, keeping most workers in this market at or below the federal poverty threshold."

In Pretoria the same volatility is evident from the large difference between the income earned in 2004 in a good month in the day labour market and the amount earned during a very bad month. This is illustrated in figure 7, which shows a striking resemblance to the case of the United States in figure 6.

${ }^{2}$ The N\$ trades at par with the ZAR and was traded at an exchange rate of ZAR 8.07 for one US\$ on 10 March 2008. 
Figure 7: The monthly income of day labourers in Pretoria in August 2004, a good month and a bad month

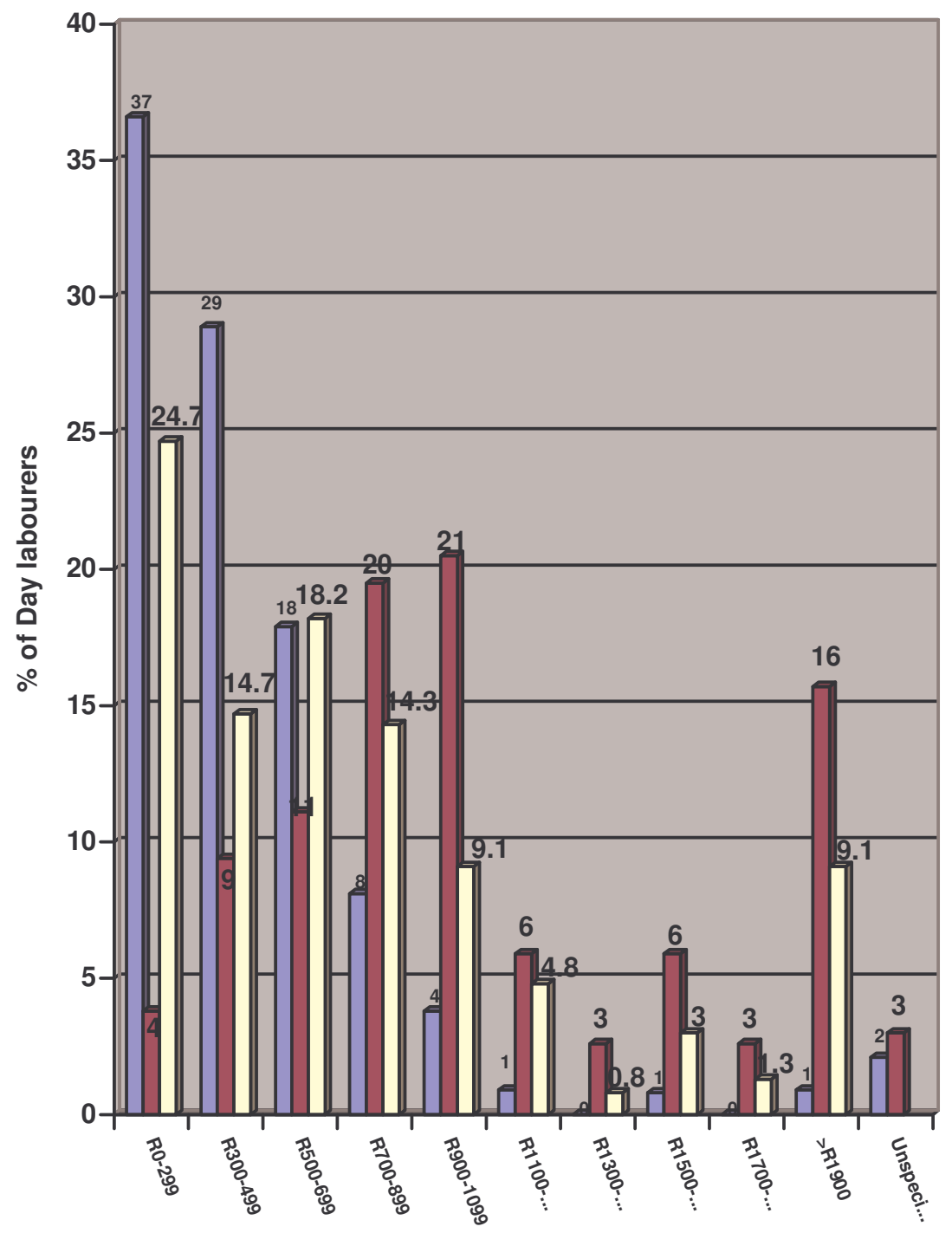

\begin{tabular}{|l|}
\hline$\square \%$ of Day \\
labourers in \\
bad month \\
$\square \%$ of Day \\
labourers in \\
good month \\
\\
$\square \%$ of Day \\
labourers in \\
September \\
2004 \\
\hline
\end{tabular}

Monthly income in Rand

Source: Survey data

In a good month of earnings almost a third or 32.7 percent of the sample population earned between R800 and R1 100 per month. There is even a group of thirty-seven or 15,7 percent of the day labourers that maintained that they earned more than R1 900 per month in good times. This paints a fairly optimistic picture, but it is the exception rather than the rule.

When times are bad, however, the picture changes drastically. In a typical month of bad earnings, the vast majority of day labourers in Pretoria earned much lower monthly wages in 2004. In fact, almost two-thirds or 65.5 percent of the sample population earned less than R500 per month during such periods in 2004. A total of 83.4 percent of the respondents earned less than R700 per month in bad times. This represents a decrease of more than 50 percent. This uncertainty has a large impact on the ability of day labourers to plan ahead and is reflected in the anxiety of the respondents about their ability to support their families (Blaauw et al., 2006:468).

More than half or 57.6 percent of the respondents earned less than R700 in the month preceding the survey in 2004. An even more significant statistic is the fact that 24.7 percent of the day labourers received an income of less than $\mathrm{R} 300$ per month. The national poverty line per adult equivalent, 
expressed in 2004 prices, was R 394 per month (United Nations Development Programme, 2003:6). This section of the sample population is without doubt living in severe poverty unless they have other means of income or support. The picture is even more somber if the work of Martins (2004) is taken into account. Martins estimated that the minimum monthly amount necessary to sustain a household of four people for Pretoria in 2004 was R 1728.10 (Martins, 2004:4). A comparison of the average monthly income of day labourers in Pretoria in 2004 with the minimum living standard monthly income in Pretoria is provided in Table 1.

Table 1: Average monthly income of day labourers compared with the minimum living level of monthly income in Pretoria in 2004.

\begin{tabular}{|c|c|c|c|c|}
\hline \multirow{2}{*}{$\begin{array}{l}\text { Average monthly } \\
\text { income of day } \\
\text { labourers in a } \\
\text { good month in } \\
2004\end{array}$} & \multirow{2}{*}{$\begin{array}{l}\text { Average monthly } \\
\text { income of day } \\
\text { labourers in a bad } \\
\text { month in } 2004\end{array}$} & \multirow{2}{*}{$\begin{array}{l}\text { Average } \\
\text { monthly income } \\
\text { of day labourers } \\
\text { in August } 2004\end{array}$} & \multicolumn{2}{|c|}{$\begin{array}{l}\text { Monthly minimum living le } \\
\text { in Pretoria by size of } \\
\text { household: } 2004\end{array}$} \\
\hline & & & $\begin{array}{l}\text { Household } \\
\text { size (no. } \\
\text { of } \\
\text { persons) }\end{array}$ & $\begin{array}{l}\text { Minimum } \\
\text { Living } \\
\text { Level ( } R \\
\text { per month) }\end{array}$ \\
\hline R 1187.46 & R 401.93 & R 672.17 & $\begin{array}{l}2 \\
3 \\
4 \\
5 \\
6\end{array}$ & $\begin{array}{lll}R & 1 & 060.29 \\
R & 1 & 398.57 \\
R & 1 & 728.10 \\
R & 2 & 052.73 \\
R & 2 & 401.02\end{array}$ \\
\hline
\end{tabular}

Source: Survey data \& Martins (2004:4)

Table 1 clearly illustrates that the average day labourer in Pretoria would have found it difficult to support four dependents (their average family size) in 2004. This was the case even in months that can be classified as exceptionally good in terms of the income that was earned.

The above data proves beyond all reasonable doubt that being a day labourer in Pretoria can provide a means of subsistence, but insufficient income is earned to support a family or other dependants. The outlook for their counterparts in Windhoek is just as bleak (Gonzo \& Plattner, 2003:64).

\section{SUMMARY OF FINDINGS AND POLICY IMPLICATIONS}

Day labour is an international phenomenon that is on the increase. On any given day in the United States, approximately 117600 workers are either looking for day labour jobs or are working as day labourers. The estimated figure for South Africa is also measured in tens of thousands, with Pretoria alone having almost 3000 people involved in this activity on a daily basis. The dynamics of the day labour market are very fluid, both in Southern Africa and in a developed country like the United States.

Day labourers in Pretoria and Windhoek were mainly male, fairly young, generally low skilled, earning low and uncertain levels of income and working under harsh conditions. This corresponds to a large degree with the demographic characteristics of the day labourers in the United States. In both the United States and Southern Africa day labour pays poorly. It was found that day labourers seldom earn more than the subsistence level of income for the respective countries discussed in the paper.

The occurrence of social problems threatening the social fabric of these communities is a reality across the Atlantic. However, the day labourers in the United States play a far more active role in their communities than the ones in Pretoria and Windhoek. What is similar, though, is that the labour laws, which are supposed to protect workers in the lower income groups, do nothing to alleviate the plight of these people. The opportunities that exist to exploit them are obvious and evidence of that happening in Pretoria and Windhoek as well as the United States is readily available. 
A significant portion of day labourers in Pretoria, Windhoek and the United States previously held formal sector jobs. Layoffs and the closure of companies were cited, by respondents who held formal sector employment in Windhoek and Pretoria as the main reasons for losing their jobs. Layoffs mainly relate to cyclical and structural changes in the economies of these countries.

The biggest difference stemming from the comparison of the situation in the United States with that in Windhoek and Pretoria is in terms of the future prospects for day labourers. The vast majority of day labourers in Pretoria, Windhoek and the United States indicated that they would like to be employed in the formal sector of the economy. For day labourers in Southern Africa though the prospect of this is extremely dim.

Long spells of unemployment and low skills levels make it difficult for day labours in Windhoek and Pretoria to get back into the formal sector. The longer they are unemployed, the more redundant their skills will become. This explains why day labourers in the two Southern African cities under review here are sometimes involved with this activity for a long period of time. Some sources referred to them as being permanently unemployed. In the United States, however, 74 percent of day labourers are involved in this activity for less than three years. This suggests that the opportunity for them to make the transition into the formal sector of the economy is far better than that of their counterparts in Southern Africa.

In countries like South Africa and Namibia, emphasis must be placed on the implementation of workforce development strategies that could improve these people's chances of crossing the divide and entering formal sector employment. At the same time the improvement of worker protection and increased access to legal services require the same attention as in the United States.

\section{CONCLUSION}

Day labour is indeed a complex phenomenon, with a number of problems, violations and abuses associated with this labour market. Some of the circumstances facing day labourers are the same irrespective of whether the day labourer is living in the United States or on the African continent. These include inadequate formal schooling, harsh working conditions and very little legal protection. Other aspects differ fundamentally. The biggest difference is the fact that a day labourer in the United States has a much better chance of making the transition into the formal sector than those living in Pretoria and Windhoek. In order to address these issues successfully, the particular set of circumstances facing day labourers in different areas must be accounted for.

\section{REFERENCES}

Blaauw PF, Louw H \& Schenck R. 2006. The employment history of day labourers in South Africa and the income they earn - a case study of day labourers in Pretoria. South African Journal of Economic and Management Sciences, NS9(4):458-471.

Bless C \& Higson-Smith C. 1995. Fundamentals of Social Research Methods - an African Perspective. $2^{\text {nd }}$ ed. Cape Town:Juta.

Chetty S. 2002. Creating a sustainable climate for fixed capital formation in the South African Development Community (SADC). Research paper No 0205, Department of Economics, Rand Afrikaans University.

Gonzo W \& Plattner IE. 2003. Unemployment in an African country: a psychological perspective. Windhoek: University of Namibia Press.

Harmse AC, Blaauw PF \& Schenck CJ. 2008. Day labourers, unemployment and socio-economic development in South Africa, unpublished research paper, University of South Africa and University of Johannesburg.

Loots AE. 1998. Job creation and economic growth. The South African Journal of Economics, 66(3):319-336. 
Martins JH. 2004. Minimum and supplemented living levels in the main and other selected urban areas of the RSA, March 2004. Bureau of Market Research, UNISA. Report number 334.

Masami I. 2000. The homeless, Contemporary Society and the Welfare State: in search of a place to live. Tokyo: Akashi Shoten.

McConnell CR, Brue SL \& Macpherson DA. 2008. Contemporary Labor Economics. $8^{\text {th }}$ ed. New York: McGraw-Hill.

Mulinge MM \& Munyae MM. 1998. The persistent growth in size and importance of the informal economy in African countries: Implications for theorising the economy and labour markets. African Sociological Review, 2(2):20-46.

Schenck R \& Louw H. 2005. An exploratory study on day labourers in Elardus Park Pretoria. Social Work/Maatskaplike Werk, 41(1):84-95.

Szirmai A. 2005. The dynamics of socio-economic development - an introduction. Cambridge: Cambridge University Press.

United Nations Development Programme (UNDP). 2003. South Africa Human Development Report 2003. Cape Town: Oxford University Press.

Valenzuela Jr. A, Theodore N, Meléndez E \& Gonzalez AL. 2006. On the corner: Day labour in the United States. Los Angeles: UCLA.

Whiteford A \& van Seventer DE. 1999. Winners and Losers: South Africa's changing income distribution in the 1990s. Menlo Park: WEFA Southern Africa. 